\title{
The Role of Borrower-Cosigner Kinship Relations on Loan Default Evidence from Italy
}

\author{
Lucia dalla Pellegrina $^{1}\left[\right.$ Antonio Scollo $^{2}$
}

Received: 26 October 2015 / Accepted: 18 July 2016 / Published online: 11 August 2016

(C) Società Italiana degli Economisti (Italian Economic Association) 2016

\begin{abstract}
Using data from a leading Italian microfinance provider we investigate the effect of kinship relations between borrowers and cosigners on loan defaults. We address causality issues using an instrumental variable built on the exogenous rule imposed by the lender that requires personal guarantees for loans exceeding $€ 5000$. Results show that the presence of closely related cosigners tends to reduce defaults. We find that this is the result of a possible combined effect of both stronger solidarity and more effective psychological pressure exerted by relatives compared to other categories of cosigners.
\end{abstract}

\footnotetext{
We are grateful to two anonymous referees, Giorgio Di Maio, Mark Labie, Polo Landoni, Emanuele Rusinà, Ariane Szafarz, and all participants at seminars at University of Mons, and at the Third European Research Conference on Microfinance, University of Agder, June 2013 for helpful comments. We also thank Nicola Benaglio, Klaas Molenaar, Marcella Corsi, Anastasia Cozarenco, Jaime Manuel Duran Navarro, Julie Lehmann, and all participants to the 13th European Microfinance Network (EMN) Annual Conference, Warsaw, 16th \& 17th June, 2016, where this paper has been awarded the 2016 European Microfinance Research Award. We are indebted to Corrado Ferretti (PerMicro) and Andrea Limone (PerMicro) for data provision, and to Isabella Brianza and Giulia Dipasquale for valuable expert support throughout the data management process. Lucia dalla Pellegrina gratefully acknowledges financial support from the Baffi Center, Bocconi University. Andrea Vinelli has provided excellent research assistance. The usual disclaimer applies.
}

Electronic supplementary material The online version of this article (doi:10.1007/s40797-016-0039-6) contains supplementary material, which is available to authorized users.

$凶 \quad$ Lucia dalla Pellegrina

lucia.dallapellegrina@unibocconi.it

1 Department of Economics Management and Statistics (DEMS), University of Milano-Bicocca, Piazza Ateneo Nuovo 1, Milano 20126, Italy

2 BNP Paribas, Milano, Italy 
Keywords Microfinance institutions · Cosigner - Repayment behavior · Loan default

JEL Classification G2 - G21 · F63 · O1

\section{Introduction}

In the last few years, microfinance has gradually departed from the traditional model of group lending in favor of several forms of individual credit, which rely on mechanisms other than joint liability in order to enforce repayment. However, the relatively poor environment in which microfinance institutions (MFIs) operate still calls for substitutes of physical collateral in order to enhance borrowers' good behavior. Therefore, evaluating the impact that non-physical guarantees exert on repayment performance remains a primary objective for lenders, in particular in the microfinance sector.

This paper concentrates on the practice of requiring cosigned individual loans. Such types of loans are frequent in many developing countries and have received positive appraisal in the microfinance literature (see, among others, Klonner and Rai 2008). It has been observed that under some circumstances cosigning mechanisms have advantages compared to more consolidated forms of guarantees traditionally adopted by group-based micro-lending. Bond and Ray (2008), for example, find that cosigned loans are preferred to group lending when the power of imposing sanctions is unequal among individuals.

We focus on the "intensity" of social relationships between borrowers and cosigners. To the best of our knowledge, the economic literature does not provide univocal predictions regarding the role that the strength of kinship relations may exert on loan repayment performance. The most relevant contributions regarding social and kinship relationships are, in fact, related to access to lending (Besanko and Thakor 1987; La Ferrara 2003; Gangopadhyay and Lensink 2005, among others). ${ }^{1}$

Regarding loan performance, it is worth considering that a fundamental role in shaping borrowers' attitude towards loan repayment may be played by the strength of the relationships subsisting between borrowers and cosigner. These could efficiently be exploited by MFIs in order to minimize losses when loans are not assisted by real guarantees. On the one hand, it is common belief that pressure from family and close neighbors can reduce moral hazard problems since these exert more credible influence and control than other individuals. Indeed, recourse to guarantors who know all borrower's whereabouts is typically equivalent to threaten their reputation by making their lack of reliability public in case of misbehavior. On the other hand, however, lenders' confidence in cosigners' ability to exert effective pressure could be potentially undermined by borrowers' expectations of solidarity in case of need. Excess-solidarity from closely related guarantors may consequently vanish their threat. Therefore, the sign and the dimension of the effects of stronger relationships on loan repayment deserves careful investigation.

Our empirical analysis aims at investigating whether different grades of kinship between borrowers and cosigners can affect borrowers' repayment behavior (loan

1 See next section for details. 
default rates). We observe 2350 loans in the period 2009-2012. Data were provided by PerMicro, a leading MFI that has been operating in Italy since 2007. PerMicro supplies individual loans for productive purposes, especially to start-up activities, and consumer credit to people of several different ethnic groups. ${ }^{2}$ Borrowers are frequently supported either by a cosigner or a network, often a religious community.

We have detailed information on the kind of relationship linking borrowers and cosigners, as well as several personal characteristics of borrowers, and granted loans. Information is available both on borrowers having extinguished their position with PerMicro (either because they have finished repaying their loan or because of debt restructuring and/or default), and on those having outstanding loans.

We handle endogeneity problems arising from the presence of unobservable elements affecting both the presence of a cosigner and the probability of default by using an instrument based on an exogenous rule established by the lender. The rule consists in the requirement of a personal guarantee in case of loans exceeding $€ 5000$. Conditional on the presence of a continuous measure of the amount borrowed, this allows identifying the effect of having different types of cosigners on default rates.

Our estimates provide evidence that loans supported by closely related cosigners perform better than other types of loans. In particular, borrowers having siblings, spouses and next-of-kin cosigners exhibit lower default rates than borrowers linked to cosigners by weaker ties. Inspecting the frequency of direct cosigners' intervention in the repayment process, we find that our results are partially explained by the fact that non-relatives are unlikely to provide financial support to the borrower, whereas family relatives - and especially close relatives - seem to actually step in and contribute to repayment when difficulties arise. We explain this result by the fact that close relatives may alleviate the problem of loan enforcement.

The paper is organized as follows. In the next section we discuss the related literature, Sect. 3 describes the dataset, Sect. presents the empirical methodology, and Sect. 5 illustrates the results. Section 6 concludes.

\section{Literature Background}

Cosigned loan arrangements are ubiquitous, both in developed and in developing countries. In developed countries, the practice of cosigning was extremely frequent in the German credit cooperatives of the Nineteenth century (Banerjee et al. 1994), which are considered as one of the most noticeable precursors of MFIs. Nowadays, many microfinance institutions in developing countries provide individual loans guaranteed by a cosigner (Ledgerwood 1999; Gangopadhyay and Lensink 2005).

The presence of a cosigner primarily acts as a signaling mechanism regarding borrowers' creditworthiness. Responsible guarantors, in fact, would not cosign a loan if they did not think the applicants were trustworthy and would be able to repay the loan (Churchill 1999; Jaunaux and Venet 2009).

Among the most noteworthy theoretical contributions regarding the relationship between cosigning practices and access to credit, Stiglitz (1990) argues that, in an

2 At the date of 23 November 2013, PerMicro has released loans for about 29 million Euro. 
asymmetric information perspective, the practice of cosigning loans increases access to funding since it transfers risk from the bank to the cosigner, thus reducing peer monitoring costs and eventually the cost of borrowing. Besanko and Thakor (1987) also demonstrate that the presence of a cosigner, by increasing collateral availability, tends to solve adverse selection problems. In a similar vein, Gangopadhyay and Lensink (2005) developed a model that provides an economic rationale for cosigning, confirming that banks can solve adverse selection problems by offering cosigned contracts that induce risky and safe firms to group together.

Besides fostering access to credit markets, it has been observed that cosigning mechanisms can influence the repayment performance of borrowers who have been admitted to credit programs, although both the sign and the dimension of the associated effects is still under intense investigation.

First, since they are in a position to assume a defaulted obligation or have property that can be confiscated, cosigners can step-in and help repaying in case of difficulties, thus making cosigned loans to record better repayment rates, ceteris paribus. Second, as highlighted by Churchill (1999), within the framework of microfinance institutions, the guarantor also acts as a vector of social pressure on the borrower, even more than as an alternative source of reimbursement. In these situations, the cosigner may lose reputation to the same extent as the borrower, so that she may be tempted to sanction the latter in case of misbehavior, especially when there are no credible alternative sanction measures, such as legal sanctions (Besley and Coate 1995).

Empirical contributions regarding the effects of cosigning are rather lacking and do not lead to univocal conclusions. Klonner and Rai (2008), for example, provide evidence that the presence of a cosigner can reduce loan default rate in organized rotating savings and credit associations in Southern India. Related to our paper, there is evidence that different types of guarantors are appraised with regard to the kind or extent of their relationship with the borrower. The strength of the relationship between borrowers and cosigners also seems to play a fundamental role in shaping borrowers' attitude towards loan repayment.

On the one hand, in fact, a cosigner related to borrowers by strong social ties may exert more credible influence and control than other individuals. Pressure from family and friends could keep borrowers honest and make them more easily repay their loans. In fact, recourse to guarantors is typically equivalent to threaten to harm the reputation of dubious borrowers by making their lack of reliability public (Jaunaux 2007). Lenders can ex-ante account for this feature. For instance, Johnstone and Marcucci (2006) show that creditors particularly appreciate close relationships between borrowers and cosigners because relatives and friends are in a better position to access information regarding the characteristics of the borrower and can therefore improve the borrower selection process. Bryan et al. (2012) confirm that the practice of cosigning loans helps those new to the credit market to leverage the assets of their cosigners (often family members) in order to build credit opportunities. Concurring with these findings, Jaunaux (2007) shows that the number of guarantors presented by the borrower has a positive effect on the likelihood of access to the loan.

On the other hand, however, close interactions may imply excess-solidarity and eventually undermine lenders' confidence in cosigners' ability to exert effective pressure. In this event, the threat exerted by the latter would be illusory. Sharma and Zeller 
(1997), based on data from microcredit programs in Bangladesh, show that the existence of a family relationship between members of the same group has a negative impact on the proportion of loans paid on due date. Cosigners also seem to discern between different types of borrowers. Karlan et al. (2009), for example, carried out a field experiment in Peru finding that non-friends tend to cosign good borrowers, while friends also accept low types.

It has been argued that, besides selection and enforcement, some other aspects of cosigning can vary with social distance. Borrowers presumably find it easier to ask friends and relatives for support rather than asking to strangers. Opportunism could also drive the choice of a closely related cosigner, since the borrower may feel legitimate to rely on her assets as a buffer in case of default.

Finally, it is important for our purposes to notice that selection issues may also provide evidence of a spurious negative relationship between the intensity of cosigning practices and good repayment performance. Klonner and Rai (2008), for example, obtain that the number of cosigners is positively correlated with defaults, arguing that this outcome may be endogenous, as borrowers who are high default risk are normally asked for more guarantors.

Nevertheless, in the economic literature there is still small and incomplete evidence about the effect of closely related cosigners versus more socially distant ones on the borrower's credit performance. There is also scarce attention towards accounting for the process of selection between potential guarantors. The result is that empirical analyses often involve contrasting features, leading to inconclusive outcomes. The main objective of this paper is trying to shed light on these issues using micro-level data on loans provided by a well-established microfinance operator in Italy.

\subsection{A Brief History of Microcredit in Italy}

Financial exclusion has always been a sensitive issue in Italy. Pawnshops, founded by Franciscan friars in the Middle Ages were the first institutions that started to lend to people in need. Other examples of solidarity loans are the Societies for Mutual Aid, born at the end of the Eighteenth century (Negro 2013). These were strongly linked to the territory and had purposes of assistance to the poorest.

The first rural bank based on principles of mutuality was founded in Padua in 1883, in order to promote solidarity among the participants. The success of this embryonic form of microfinance institution has been enormous, so much so that in 1920 there were 3340 rural banks spread in the country (Negro 2013).

In 2012 and 2013, 23 microfinance institutions were surveyed in Italy. The overall amount of loans disbursed in 2012 and 2013 has been 25,142,356 euros and 64,600,497 euros respectively (Botti and Negro 2014). In particular, recent social performance analyses of the Italian microcredit industry showed a strong focus on the most disadvantaged target groups (migrants, youth and victims of usury practices) while, at the same time, a poor ability to serve women clients (Botti and Corsi 2010). Furthermore, during the financial crisis of 2007-2010, there has been a significant increase in 
the volume of microloans disbursed by Italian MFIs (460\% increase recorded in the number of loans and $209 \%$ increase in their volume) (FGDA ${ }^{3}$ and Jayo et al. 2010).

According to the UE definition, microcredit is a loan with amount not exceeding 25 thousand euros. Despite the UE only recognizes business lending, in Italy there is a tendency to recognize also the importance of consumer credit (also defined social microcredit). However, unlike micro-credit to small business, the latter does not involve any forms of guarantee, even in the form of pledgeable income. Therefore, for this type of loans, risk coverage tools alternatives to physical capital are particularly needed, especially when they are individually based, rather than in the form of group lending.

There are both similarities and differences between microcredit granted in Italy and other European countries and the most common forms of microcredit provided by MFIs in LDCs. On the one hand, as in the case of microcredit in LDCs, additional services such as training, monitoring and assistance, are strictly inseparable elements associated to the loan, especially when businesses are involved.

On the other hand, mainly because of the absence of a legislative framework disciplining microfinance, micro-loans in Italy are usually disbursed through the involvement of more than one institution. Typically, banks physically allocate credit to the borrowers, whereas a public or private institution establishes a guarantee fund covering any losses that banks may incur, thereby guaranteeing the bank against the risk of default. Finally, other (generally non-profit) organizations handle the loan management phase, providing customer support during the formal procedures.

\section{Data}

Data have been drawn from a database of 2350 loans accorded by PerMicro in the period from 1 September 2009 to 31 October 2012 (observation date). ${ }^{4}$ The data include all borrowers who have either extinguished their relationship with the lender or have an outstanding loan in correspondence of the observation date. Repeated loans to the same borrowers are not frequent $(1.5 \%) .^{5}$

The lending activity of PerMicro is carried out by twelve branches located in the Northern/Central area of the country. ${ }^{6}$ All agencies operate through individual lending. Loans are repaid in a variable number of monthly installments (install_number) with a minimum of 12 and a maximum of 60 .

More in detail, 626 credit positions have been regularly extinguished (26.6\% of the cases). There are 110 defaults $(4.7 \%), 43$ of which have been passed to recov-

\footnotetext{
3 Fondazione Giordano dell'Amore (http://www.fgda.org/).

4 Data pertain to one individual MFI. On the one hand, this may be considered a shortcoming due to lack of representativeness. On the other hand, because there is only one MFI, a large part of the heterogeneities come from the borrowers' characteristics and not from the lender's, which helps identifying the effects of the presence of cosigners on repayment rates.

5 The relatively low number of repeated loans is due to the combination of both the relatively recent establishment of PerMicro and the average length of loans (more than 30 months, see below). Note that restructured loans are not accounted for twice.

6 All information refer to the observation date. At the date of 26 July 2016, for instance, branches are 14.
} 
Table 1 Loan state: extinguished, outstanding, default

\begin{tabular}{|c|c|c|c|c|c|c|}
\hline & \multicolumn{2}{|c|}{ Full sample 2350 obs. } & \multicolumn{2}{|c|}{ Cosigned loans 1321 obs. } & \multicolumn{2}{|c|}{ Non-cosigned loans 1029 obs } \\
\hline & Freq. & Percent & Freq. & Percent & Freq. & Percent \\
\hline Extinguished & 626 & 26.6 & 355 & 26.9 & 271 & 26.3 \\
\hline Outstanding & 1614 & 68.7 & 905 & 68.5 & 709 & 68.9 \\
\hline Default & 110 & 4.7 & 61 & 4.6 & 49 & 4.8 \\
\hline
\end{tabular}

Source: PerMicro database

ery by means of a specific legal procedure, while the others are recorded as losses. ${ }^{7}$ The remaining ones $(68.7 \%)$ consist of outstanding loans for which the borrower keeps repaying regularly. ${ }^{8}$ Details are reported in Table 1 , including statistics on the sub-samples of loans with and without cosigner. Apparently there are no substantial differences in the share of loans belonging to each category-Extinguished, Outstanding, Default — when considering the full sample and the sub-samples of cosigned and non-cosigned agreements. In particular, the percentage of defaults looks alike in the three samples.

As reported in Table 2, the loan average principal (principal) is $€ 5345$, with a minimum of $€ 876$ and a maximum of $€ 28,000$. The average amount of installments (install_amount) is $€ 198$. Interest rate (interest_rate) ranges from 0 to $16 \%$, yet most of the loans are accorded a fixed interest of $11.9 \%$. Physical collateral is never required.

Guarantors may be of two types: cosigners (56.2\% of the loans) and informal networks $(29.1 \%)$. The most substantial difference between the two is that the former are jointly liable with the borrower in case of default. Cosigners are also required to pay late charges, fines, and penalties, in case the original borrower fails to do so. Networks, instead, only provide informal moral guarantees on the borrower's social background to testify that she belongs to community held in sufficient esteem.

A crucial feature for our purposes is that PerMicro requires the presence of a cosigner when the loan principal exceeds $€ 5000$, although borrowers may propose a cosigner for lower amounts. There are few cases in which borrowers are waived from presenting a cosigner on loans above $€$ 5000. In our dataset, for example, we have observed that, for loans below $€ 5000$, borrowers with cosigners are in the number of $471(41 \%)$, while those without cosigners are 680. Conversely, 850 loans larger than $€ 5000$, are cosigned (71\%). In spite of the fact that the rule is not perfectly enforced, there is substantial difference in the frequency of cosigning loans above and below the threshold of $€ 5000$.

We have information regarding both the share of cosigned loans and the kinship relation between each individual borrower and her cosigner. Based on this information,

\footnotetext{
7 The classification of defaulting loans is made by the lender.

8 There are some cases in which repayment delays occur but the latter are not considered enough severe by the lender so as to either start a legal recovery procedure or record them as losses. Restructured loans are also included in this category.
} 
Table 2 Summary statistics

\begin{tabular}{|c|c|c|c|c|c|}
\hline Variable: description & Variable: label & Mean & Std. Dev. & Min & Max \\
\hline Year of birth & birth_year & 1971 & 10.62 & 1937 & 1993 \\
\hline Time of arrival in Italy (years) ${ }^{\mathrm{a}}$ & Italy_since & 0.382 & 0.047 & 0 & 0.482 \\
\hline Gender $($ male $=1)$ & gender & 0.410 & & 0 & 1 \\
\hline Education: primary (yes = 1) & edu_primary & 0.015 & & 0 & 1 \\
\hline Education: secondary (yes = 1) & edu_secondary & 0.226 & & 0 & 1 \\
\hline Education: professional (yes = 1) & $e d u \_p r o f$ & 0.330 & & 0 & 1 \\
\hline Education: upper-secondary (yes = 1) & $e d u \_h i g h$ & 0.084 & & 0 & 1 \\
\hline Education: bachelor (yes = 1) & edu_bachelor & 0.120 & & 0 & 1 \\
\hline Marital status (married = 1) & married & 0.552 & & 0 & 1 \\
\hline Number of children ${ }^{b}$ & children & 1.376 & 1.292 & 0 & 8 \\
\hline House $(\text { ownership }=1)^{\mathrm{c}}$ & house_own & 0.049 & & 0 & 1 \\
\hline Knowledge Italian language (yes $=1$ ) & Italian_lang & 0.788 & & 0 & 1 \\
\hline Stable employment position $(\text { yes }=1)^{\mathrm{c}}$ & stable_work & 0.811 & & 0 & 1 \\
\hline Monthly income (th. euro) & income & 1.063 & 0.428 & 0 & 4.318 \\
\hline Sends money home $(\text { yes }=1)^{c}$ & money_home & 0.577 & & 0 & 1 \\
\hline Monthly savings (th. euro) ${ }^{\mathrm{d}}$ & savings & 0.585 & 0.398 & 0 & 2.700 \\
\hline Consumer lending & cons_lending & 0.815 & & 0 & 1 \\
\hline Loan: principal (th. euro) & principal & 5.346 & 3.193 & 0.876 & 28.000 \\
\hline Loan: month of the first installment $\mathrm{t}^{\mathrm{e}}$ & loan_start & 43.051 & 10.286 & 19 & 58 \\
\hline Installments: number & install_number & 31.409 & 12.716 & 12 & 60 \\
\hline Installments: amount (th. euro) & install_amount & 0.198 & 0.081 & 0.019 & 0.624 \\
\hline Interest rate $(\%)$ & interest_rate & 10.759 & 2.623 & 0 & 16 \\
\hline Network guarantee (yes $=1$ ) & net & 0.291 & & 0 & 1 \\
\hline Cosigner $($ yes = 1) & co_yes & 0.562 & & 0 & 1 \\
\hline $\begin{array}{l}\text { Cosigner: next-of-kin, spouse, sibling, } \\
\text { other relative }(\text { yes }=1)\end{array}$ & co_weak & 0.217 & & 0 & 1 \\
\hline $\begin{array}{l}\text { Cosigner: next-of-kin, spouse, sibling } \\
\quad(\text { yes }=1)\end{array}$ & co_close & 0.127 & & 0 & 1 \\
\hline Cosigner: monthly income (th. euro) ${ }^{\mathrm{f}}$ & co_income & 1.073 & 0.369 & 0 & 6.387 \\
\hline
\end{tabular}

Source: PerMicro database: 2350 observations

${ }^{a}$ Initial date: 01/01/1900. Variable divided by 100

${ }^{b}$ Missing values filled in using a negative binomial regression with bootstrapping imputation method

${ }^{\mathrm{c}}$ Missing values filled in using a logistic regression with bootstrapping imputation method

${ }^{\mathrm{d}}$ Missing values filled in using an OLS regression with bootstrapping imputation method

e Initial date: 01/01/2008. This variable also indicates the number of months of experience accumulated by PerMicro upon activation of the loan

${ }^{\mathrm{f}}$ Computed on the sub-sample of cosigned loans (1321 obs)

we built a dummy variable taking value 1 when a cosigner is present (co_yes), and 0 otherwise. Two additional dummy variables aimed at capturing the strength of the borrower-cosigner relationship were also constructed. The first (co_weak) takes value 1 when cosigners are siblings, spouses, next-of-kin, and other types of relatives $(21.7 \%$ 
of the loans), hence excluding friends and neighbors. The second dummy further excludes the other types of relatives ( $12.7 \%$ of the loans), thus measuring the impact of stronger kinship relations (co_close). A binary variable indicating the involvement of informal network guarantees (net) has also been considered. ${ }^{9}$

The effect of cosigning relationships on repayment diligence is investigated through the analysis of loan defaults. The latter are measured by a dummy variable (default) taking value 1 if the borrower did not fully repay her loan, and 0 otherwise. More precisely, in the event of a default, the lender can decide to either pursue legal procedures for recovery or to record a loss.

We combined the information on the presence of cosigners and on borrowers' repayment performance. As we already noticed, there does not seem to be any strong correlation between the two measures, since the two sub-samples of cosigned and non-cosigned loans show no difference in the average number of defaults (Table 1). However, lack of correlation could be due to various forms of selection and endogeneity (see Sect. 4.1 for details).

As for other characteristics, summary statistics in Table 2 show that $81.1 \%$ of the borrowers have a stable working position (stable_work). In addition, we consider fixed-effects related to the type of business conducted by the borrowers. A detailed breakdown of the borrowers' job sector shows that most of them (1096) either operate in personal care services (mainly as housemaids and caring for the elderly) or are workmen (627), while 260 declare they carry out an independent activity as selfemployed. In smaller percentages, farmers, drivers, shopkeepers, craftsmen, doctors and nurses, accountants, waiters, teachers, and students are also included. From this perspective, the main difference between borrowers with and without cosigner is that the former category includes a slightly higher share of self-employed workers.

From information regarding the declared purpose of the loan, it emerges that, to a large extent, it goes to support home/consumption expenditure, although indications regarding the final destination of the remaining share of loans are rather ambiguous. Most importantly, there seems to be evidence pointing to the presence of a cosigner for credit having productive purposes (1084 loans), possibly because productive loans are of a larger size. Anyway, all specifications include a dummy variable (cons_lending) taking value 1 in case PerMicro classifies the loan as "consumer credit", and 0 otherwise (see Table 2).

Besides job sector and purpose of the loan, there are other elements affecting repayment performance. We consider a continuous variable (income) representing the sum of wage and other earnings, which amount to 80 and $20 \%$ of total earnings, respectively. The borrowers' savings and whether they send money to relatives in their countries of origin (money_home) are also taken into account.

The dataset also includes personal information on the borrower, such as the year of birth (birth_year), which is on average 1971, gender (41\% male), and dummies capturing the educational level attained (edu_primary, edu_secondary, edu_prof, edu_high, edu_bachelor). The borrowers' marital status (married), number of children (children), house ownership (house_own), time of arrival in Italy (Italy_since), and knowledge

9 Although there are few cases in which both a cosigner and network guarantees are present, having multiple cosigners (see for example Klonner and Rai 2008) is not possible. 
of the language (Italian_lang), are also used as control variables. In addition, we have data on cosigners' income (co_income) ${ }^{10}$ All details are summarized in Table 2.

In few cases, borrowers did not provide details on one of their characteristics, although exhaustively submitting all the other data, including those regarding the basic features of the loan. Under such conditions, dropping observations regarding these borrowers seemed inconsistent with the main purpose of the paper. We avoided doing so, since this would also have given rise to a sample-selection bias in case of lack of fulfillment of a "missing at random" condition. We have thus tackled the problem of missing data by replacing unavailable observations with estimates obtained regressing five variables not reporting full information (children, house_own, stable_work, money_home, and savings) on all other variables reported in Table 2, except those related to cosigners. We used the predicted values from these regressions to fill in non-available observations. ${ }^{11}$

Finally, Table 3 reports statistics on the covariates comparing the sub-samples of loans with and without cosigner. Figures do not exhibit any substantial discrepancy between average values of the variables. Some interesting differences concern the presence of informal network guarantees (lower for cosigned customers, thus highlighting some degree of substitutability between the two types of guarantees), savings (slightly higher for cosigned customers), features related to borrowers' activity and working position, such as a higher percentage of productive loans and a lower share of stable employment contracts associated to cosigned loans. In particular, it is worth noting that, according to the rule established by PerMicro requiring a personal guarantee on loans exceeding $€ 5000$ (see above), a considerably higher principal goes hand in hand with cosigned agreements (the difference is on average $€ 1000$ ).

\section{Empirical Methodology}

We estimate the following equations ${ }^{12}$ :

$$
\begin{gathered}
c o_{-i j}=\alpha_{0}+\beta_{0} X_{i j}+\delta z_{i j}+\mu_{j}^{c}+\vartheta_{i j} \\
\text { default }_{i j}=\alpha_{1}+\beta_{1} X_{i j}+\gamma \widehat{c o \_} \_i j+\mu_{j}^{d}+\varepsilon_{i j}
\end{gathered}
$$

where $i$ identifies the individual borrower, and $j$ refers to several types of fixed effects (see below for details). In particular, $\mathrm{Co}_{-} i j$ are variables reflecting the role of the borrower-cosigner relationship on default rates (co_yes, co_weak, co_close) alternatively entering equation (1). Hat variables in (2) are the associated fitted values.

\footnotetext{
10 This variable will be used to construct a proxy of cosigners' expected financial support in the repayment process. Details are provided in the next section.

11 Missing values have been filled in using a logistic regression for binary variables, a negative binomial regression for count variables, and OLS for continuous variables (see Table 2 for details). Bootstrapping techniques have been applied to all regressions.

12 Guttman (2007) previously used a similar reduced-sample approach in the study of the repayment behavior in microfinance programs, although not contemplating borrowers with cosigned loans.
} 
Table 3 Summary statistics: borrowers with and without cosigner

\begin{tabular}{|c|c|c|c|c|c|}
\hline \multirow[t]{2}{*}{ Variable: description } & \multicolumn{2}{|c|}{ Cosigned loans ${ }^{\mathrm{a}}$} & \multicolumn{2}{|c|}{ Non-cosigned loans ${ }^{b}$} & \multirow{2}{*}{$\begin{array}{l}t \text { test for mean } \\
\text { comparison }^{c}\end{array}$} \\
\hline & Mean & Std. Dev. & Mean & Std. Dev. & \\
\hline Year of birth & 1971 & 10.786 & 1970 & 10.353 & $-3.0148^{*}$ \\
\hline Time of arrival in Italy (years) ${ }^{\mathrm{d}}$ & 0.392 & 0.048 & 0.389 & 0.050 & -1.3523 \\
\hline Gender $($ male $=1)$ & 0.430 & 0.495 & 0.384 & 0.487 & $-2.2564^{*}$ \\
\hline Education: primary (yes = 1) & 0.014 & 0.119 & 0.017 & 0.128 & 0.4185 \\
\hline Education: secondary (yes $=1$ ) & 0.207 & 0.406 & 0.249 & 0.433 & $2.3824^{*}$ \\
\hline Education: professional (yes = 1) & 0.077 & 0.267 & 0.297 & 0.457 & 1.3111 \\
\hline Education: upper-secondary (yes $=1$ ) & 0.355 & 0.479 & 0.092 & 0.290 & $-2.9538^{*}$ \\
\hline Education: bachelor (yes = 1) & 0.129 & 0.335 & 0.108 & 0.310 & -1.5433 \\
\hline Marital status (married = 1) & 0.593 & 0.491 & 0.499 & 0.500 & $-4.6107^{*}$ \\
\hline Number of children & 1.331 & 1.270 & 1.424 & 1.321 & $1.7284^{*}$ \\
\hline House (ownership = 1) & 0.054 & 0.226 & 0.042 & 0.200 & -1.3387 \\
\hline Knowledge Italian language $($ yes $=1)$ & 0.786 & 0.410 & 0.791 & 0.407 & 0.3113 \\
\hline Stable employment position $($ yes $=1$ ) & 0.750 & 0.433 & 0.879 & 0.327 & $7.9114^{*}$ \\
\hline Monthly income (th. euro) & 1.044 & 0.457 & 1.088 & 0.385 & $2.4423^{*}$ \\
\hline Sends money home (yes = 1) & 0.549 & 0.498 & 0.620 & 0.486 & $3.4766^{*}$ \\
\hline Monthly savings (th. euro) & 0.600 & 0.994 & 0.479 & 0.295 & $-3.7491^{*}$ \\
\hline Consumer lending & 0.771 & 0.421 & 0.872 & 0.335 & $6.3103^{*}$ \\
\hline Loan: principal (th. euro) & 6.327 & 3.487 & 4.087 & 2.207 & $-17.9924^{*}$ \\
\hline Loan: month of the first installment $\mathrm{e}^{\mathrm{e}}$ & 41.867 & 9.822 & 44.604 & 10.410 & $6.5300^{*}$ \\
\hline Installments: number & 34.256 & 12.824 & 27.755 & 11.598 & $-12.7087^{*}$ \\
\hline Installments: amount (th. euro) & 0.220 & 0.087 & 0.170 & 0.061 & $-15.4772^{*}$ \\
\hline Interest rate $(\%)$ & 11.297 & 1.648 & 10.069 & 3.374 & $-11.5742^{*}$ \\
\hline Network guarantee $($ yes $=1)$ & 0.196 & 0.397 & 0.414 & 0.493 & $11.8694^{*}$ \\
\hline
\end{tabular}

Source: PerMicro database

a 1321 obs

b 1029 obs

${ }^{\mathrm{c}} t$ statistic is reported, * indicates significance at either 1,5 and $10 \%$ level

d Initial date: 01/01/1900. Variable divided by 100

e Initial date: 01/01/2008. This variable also indicates the number of months of experience accumulated by PerMicro upon activation of the loan

The parameter $\gamma$, which is our main focus of attention, can be interpreted as the change in the likelihood of default due to the presence of a cosigner (or a given category of cosigners), compared to the situation when lending is not assisted by such guarantee.

$X_{i j}$ is a vector of general characteristics of the borrower, such as age, gender, education and other personal traits. Variables seizing on both the relationship network and the extent of social and cultural integration are also included, along with all the other covariates described in Table 2. $\vartheta_{i j}$ and $\varepsilon_{i j}$ are idiosyncratic errors, such as $\mathrm{E}\left(\vartheta_{i j} \mid X_{i j}, z_{i j}, \mu_{j}^{c}\right)=0$ and $\mathrm{E}\left(\varepsilon_{i j} \mid X_{i j}, c o_{-i j}, \mu_{j}^{d}\right)=0$. Standard errors are clustered at country (borrowers' nationality) level. $z_{i j}$ is an instrumental variable explaining $c o \_i j$ but not correlated with $\varepsilon_{i j}$ (see next sub-section). 
Fixed-effects are summarized in $\mu_{j}$, where $j$ may alternatively refer to different specificities. As previously mentioned, job sector and declared loan purpose are considered as fixed-effects. Then, we include branch dummies, since agencies may differ in terms of quality of the employees, ability of the staff in selecting borrowers and soliciting for repayment, and geographical features affecting the probability of repaying on a regular basis (such as unemployment). ${ }^{13}$ We will report only the estimates of the Job sector Fixed-Effects model. The empirical results of the Loan purpose and Branch Fixed-Effects models do not substantially depart from this. ${ }^{14}$

Finally, it is worth noticing that since defaults rarely take place without a sufficient number of installments being overdue, we opted for confining the regression analysis to 1789 loans outstanding from at least six months. This choice is driven by the fact that defaults rarely take place without a sufficient number of installments being overdue. ${ }^{15}$ Then we extend our analysis to the full set of loans for robustness check, exploiting the presence of a covariate that accounts for the loan starting date (loan_start) as control relative to recent loans. ${ }^{16}$ Notice that this variable takes higher values for more recent agreements, thus also capturing the experience accumulated by PerMicro upon activation of the loan.

\subsection{Selection Process and Endogeneity}

Endogeneity may stem from some borrowers' unmeasurable characteristics which simultaneously affect the probability of default and the presence of a cosigner. Our most likely explanation for this phenomenon is that, ceteris paribus, soft information may induce the lender to invite riskier customers to present a cosigner regardless of the loan amount they are accorded. If additional risk is positively correlated with default, something that looks rather plausible, a positive relation between cosigning and default would be observed. ${ }^{17}$ Furthermore, it seems likely that potential cosigners expressing stronger solidarity would be more inclined to provide riskier borrowers with guarantees. Relatives - especially closer ones - seem good candidates in this case, so that the misleadingly positive relation described above would be the outcome of closer relatives cosigning worse borrowers.

In addition, it is possible that better borrowers have higher reputational concerns, a fact that could lead them to count exclusively on their own resources for loan repayment. Conversely, bad borrowers may attempt to exploit the possibility of cosigners'

\footnotetext{
13 Since default takes value 0 when either the loan is outstanding or extinguished, controlling for the state of the loan makes little sense (i.e., the corresponding estimated marginal effects would be equal to either 1 or -1$)$.

14 Results available upon request.

15 The risk committee of PerMicro discusses the possibility of assigning the practice to a lawyer after four overdue installments (i.e. at the fifth month after obtaining the loan).

16 We used January 2008 as a starting month for the counting process.

17 Klonner and Rai (2008), for example, show that the number of cosigners is positively correlated with defaults, arguing that this may occur because borrowers who have high default risk are asked for more cosigners. However, when looking for a causality relation, the authors find that the number of cosigners has a negative causal effect on defaults.
} 
Table 4 Instrument: summary statistics

\begin{tabular}{|c|c|c|c|c|c|c|}
\hline Variable & Sample & Obs & Mean & Std. Dev. & Min & $\operatorname{Max}$ \\
\hline \multirow{4}{*}{$\begin{array}{l}\text { threshold (loan is above } € \\
\text { 5000) }\end{array}$} & Non cosigned loans; $c_{\text {co_yes }}=0$ & 1029 & 0.34 & 0.47 & 0 & 1 \\
\hline & Cosigned loans; co_yes $=1$ & 1321 & 0.65 & 0.47 & 0 & 1 \\
\hline & $\begin{array}{l}\text { Loans cosigned by all relatives; } \\
\text { co_weak }=1\end{array}$ & 591 & 0.60 & 0.49 & 0 & 1 \\
\hline & $\begin{array}{l}\text { Loans cosigned by next-of-kin, } \\
\text { spouses, siblings (close kinship); } \\
\text { co_close }=1\end{array}$ & 299 & 0.56 & 0.49 & 0 & 1 \\
\hline
\end{tabular}

Source: PerMicro database

intervention in the repayment process to reduce the risk of their own assets being seized in case of a default. Again, we would end up with a positive sign of the parameter $\gamma$ in equation (1), which would still be the mere result of hidden features, eventually leading to identification problems.

Therefore, besides using a comprehensive set of covariates with the aim of reducing the correlation between the presence of a cosigner and unmeasurable components of repayment performance, instrumental variables techniques are employed. The instrument adopted is based on the requirement, established by PerMicro, of a cosigner if the principal is above $€ 5000$ (see Sect. 3). This information is converted into a binary variable (threshold) taking value 1 when such larger loans are accorded.

Summary statistics concerning the instrument used are reported in Table 4, both for the full sample of borrowers and the sub-samples of cosigned and non-cosigned loans. In particular, the choice of our instrument relies on two elements: (i) sufficiently high predictive power in terms of the variables measuring the likelihood of having a cosigner; (ii) absence of correlation with unmeasurable features explaining the probability of default.

As for (i) we report in Table 4 summary statistics for threshold according to the intensity of her kinship relation with the borrower. As a general indication, it is worth noticing that the share of loans with principals above $€ 5000$ is considerably higher among the category of cosigned agreements. In fact, comparing cosigned and noncosigned loans (regardless of the existence of any kinship relation between the parties involved) in excess of $€ 5000$, it is possible to observe that the latter are $34 \%$ of loans granted above that threshold, while $65 \%$ are cosigned. Hence, even if this highlights the fact that the lender does not strictly enforce the rule of the $€ 5000$ limit, one can be confident that the predictive power of the dummy threshold in terms of cosigning variables is sufficiently large. Correlations reported in Table 5 confirm the above.

As for (ii) in Table 5 we also report the correlation between the instrument and our measure of default, which is approximately zero. Like in previous contributions made to the literature on microcredit, the exclusion restrictions for instruments consisting of exogenous rules set up by lenders hold conditional on the inclusion of a continuous measure of the variable on which the rule is designed (see, among others, Pitt and Khandker 1998, and Dalla Pellegrina 2011). In our case the required measure 
Table 5 Correlation between the instrument and variables measuring the intensity of kinship relations between borrowers and cosigners

\begin{tabular}{lclll}
\hline & threshold & default & co_yes & co_weak \\
\hline default & -0.0301 & 1 & & \\
co_yes & $0.3050^{*}$ & -0.0034 & 1 & \\
co_weak & $0.1856^{*}$ & $0.0443^{*}$ & $0.4652^{*}$ & 1 \\
co_close & $0.1301^{*}$ & $0.0726^{*}$ & $0.3370^{*}$ & $0.7243^{*}$ \\
\hline
\end{tabular}

Source: PerMicro database; * indicates correlation coefficients significant at the $5 \%$ level or better

is the amount lent. In this way, the instrument should affect the probability of having a cosigner while not being simultaneously correlated with unmeasurable features explaining repayment rates conditional on all other covariates. ${ }^{18}$

\subsection{Testing Solidarity Versus Cosigners' Intervention Hypotheses}

In our context it would be interesting trying to further investigate whether having the loan cosigned by a close relative actually strengthens the borrower's commitment towards repayment. Another-not necessarily alternative-hypothesis is that, due to higher solidarity, closer relatives are more likely than other individuals to step in to repay the loan on behalf of the borrower.

We attempt to shed light on this important issue by introducing a variable indicating the expectation of cosigners' intervention in the loan repayment process. ${ }^{19}$ It consists of a measure of the extent to which cosigners' income exceeds extra savings remaining to the borrower after repayment of the monthly installment: ${ }^{20}$

$$
\frac{\text { cosigner's income }- \text { (borrower's savings }- \text { installment amount) }}{\text { cosigner's income }}
$$

From the descriptive statistics computed on the sub-sample of cosigned loans it emerges that the average expected rate of cosigners' intervention is rather high $(0.52$, with standard deviation of 0.37 ).

Besides being interested in estimating the size of potential financial support, our main purpose is to see if, and to what extent, the parameters associated to the presence

\footnotetext{
18 As remarked by Pitt and Khandker, a necessary condition for the validity of their instrument (ownership of less than 0.5 acres of land) is that credit cannot be used to buy additional land. In their 1998 paper the authors exclude this possibility arguing that in Bangladesh the land market is rather static and land is merely inherited. Likewise, we make a similar assumption in that obtaining a loan of a given amount does not necessarily increase the opportunity of being accorded larger loans in the future. In other words, loans are not progressive in the amount. As a matter of fact, we do not frequently observe a borrower more than once in our dataset, unless her debt is re-negotiated.

19 This measure has been suggested by experts at PerMicro.

20 The variable has been censored so as to set it in the $[0,1]$ interval.
} 
of (certain types of) cosigners are affected by the inclusion of a measure of cosigners' intervention.

\section{Results}

Two-Stage Least Squares (2SLS) estimates of equations (1), (2) are presented in Table 6 for the sample of 17896 -month outstanding loans. ${ }^{21}$

In details, estimates of equation (1) (first-stage) are shown in columns (a), (c) and (e). The dependent variables are respectively: co_yes, expressing whether the loan is cosigned or not; co_weak, indicating whether the cosigner and the borrower are relatives; and co_close, capturing only strong kinship relations between borrowers and cosigners. The remaining columns refer to equation (2) (second-stage), where the dependent variable is the default rate.

The first important result emerging from the sign of the estimated regression coefficients is that the presence of a cosigner, irrespective of her relationship with the borrower, significantly improves repayment performance (columns (b), (d) and (f)). Furthermore, when exploring the specific features of the borrower-cosigner relations, we find that kinship has a more substantial role in reducing defaults (columns (d) and (f)). Most important, it must be noticed that shifting from column (b), to (d) and then (f) (i.e. from weakly to strongly related cosigners), parameters are ranked according to the strength of the borrower-cosigner relationship, supporting the hypothesis that the closer the borrower-cosigner kinship relation, the better repayment diligence is.

Moreover, as the magnitude of the parameters suggests, estimated effects are considerable in size. For example, we observe that simply having a cosigned loan leads on average to a 25 per cent decrease of the probability of default (column (b)), while having a relative as cosigner reduces this probability to 52 per cent (column (d)). A close relative as cosigner further decreases the likelihood of default to 69 per cent (column (f)).

First-Stage regressions also provide important indications in terms of the selection process taking place when deciding the presence of a cosigner in a given loan. In fact, the dummy threshold is positively correlated with both the presence of a generic cosigner and of a relative cosigner. Weak identification tests (see bottom of each table) suggest that the instrument has sufficiently high predictive power to explain both the presence of a cosigner and the varying extent of the borrower-cosigner relationship. In particular, the Kleibergen-Paap F statistic attains noticeably high values in regressions having co-yes as a dependent variable (column (a)). The test provides satisfactory results in the other cases as well.

There are also noteworthy insights to be derived from the estimates concerning other covariates. In terms of loan characteristics, we find that in general cosigners are more frequent on larger loans, as confirmed by the positive sign corresponding to principal in first-stage regressions (column (a)). However, it is interesting to note that

\footnotetext{
21 Results obtained using a Probit Two-Stage Least Square technique do not provide substantially different outcome (available upon request).
} 
Table 6 Effect of the presence of cosigners on loan default rates_-Job sector Fixed Effects-6-month outstanding loans

\begin{tabular}{|c|c|c|c|c|c|c|}
\hline & $\begin{array}{l}\text { First-stage } \\
\text { (a) }\end{array}$ & $\begin{array}{l}\text { Second-stage } \\
\text { (b) }\end{array}$ & $\begin{array}{l}\text { First-stage } \\
\text { (c) }\end{array}$ & $\begin{array}{l}\text { Second-stage } \\
\text { (d) }\end{array}$ & $\begin{array}{l}\text { First-stage } \\
\text { (e) }\end{array}$ & $\begin{array}{l}\text { Second-stage } \\
\text { (f) }\end{array}$ \\
\hline threshold & $\begin{array}{l}0.179 * * * \\
(0.048)\end{array}$ & & $\begin{array}{l}0.085 * * * \\
(0.021)\end{array}$ & & $\begin{array}{l}0.064 * * * \\
(0.020)\end{array}$ & \\
\hline co_yes & & $\begin{array}{l}-0.246^{* *} \\
(0.124)\end{array}$ & & & & \\
\hline co_weak & & & & $\begin{array}{l}-0.519 * * * \\
(0.196)\end{array}$ & & \\
\hline co_close & & & & & & $\begin{array}{l}-0.690 * * \\
(0.292)\end{array}$ \\
\hline birth_year & $\begin{array}{l}0.002 \\
(0.002)\end{array}$ & $\begin{array}{l}0.001 \\
(0.001)\end{array}$ & $\begin{array}{l}0.003 * * \\
(0.002)\end{array}$ & $\begin{array}{l}0.002 * \\
(0.001)\end{array}$ & $\begin{array}{l}0.001 \\
(0.001)\end{array}$ & $\begin{array}{l}0.001 \\
(0.001)\end{array}$ \\
\hline gender & $\begin{array}{l}0.040 \\
(0.025)\end{array}$ & $\begin{array}{l}0.040 * * * \\
(0.014)\end{array}$ & $\begin{array}{l}0.017 \\
(0.024)\end{array}$ & $\begin{array}{l}0.038 * * \\
(0.018)\end{array}$ & $\begin{array}{l}0.006 \\
(0.020)\end{array}$ & $\begin{array}{l}0.034 * \\
(0.019)\end{array}$ \\
\hline edu_high & $\begin{array}{l}0.065^{* *} \\
(0.027)\end{array}$ & $\begin{array}{l}0.005 \\
(0.015)\end{array}$ & $\begin{array}{l}0.093 * * * \\
(0.019)\end{array}$ & $\begin{array}{l}0.037 \\
(0.024)\end{array}$ & $\begin{array}{l}0.067 * * * \\
(0.019)\end{array}$ & $\begin{array}{l}0.035 \\
(0.028)\end{array}$ \\
\hline$e d u \_p r o f$ & $\begin{array}{l}0.008 \\
(0.039)\end{array}$ & $\begin{array}{l}-0.027 \\
(0.021)\end{array}$ & $\begin{array}{l}-0.060 * * * \\
(0.021)\end{array}$ & $\begin{array}{l}-0.060 * * * \\
(0.023)\end{array}$ & $\begin{array}{l}-0.072^{* * * *} \\
(0.023)\end{array}$ & $\begin{array}{l}-0.078^{* * * *} \\
(0.030)\end{array}$ \\
\hline married & $\begin{array}{l}0.121 * * * \\
(0.024)\end{array}$ & $\begin{array}{l}0.021 \\
(0.017)\end{array}$ & $\begin{array}{l}0.116^{* * *} \\
(0.025)\end{array}$ & $\begin{array}{l}0.052 * \\
(0.028)\end{array}$ & $\begin{array}{l}0.076^{* * * *} \\
(0.024)\end{array}$ & $\begin{array}{l}0.044 \\
(0.029)\end{array}$ \\
\hline house_own & $\begin{array}{l}-0.020 \\
(0.046)\end{array}$ & $\begin{array}{l}-0.033^{* *} \\
(0.015)\end{array}$ & $\begin{array}{l}0.056 \\
(0.066)\end{array}$ & $\begin{array}{l}0.001 \\
(0.040)\end{array}$ & $\begin{array}{l}0.066 \\
(0.048)\end{array}$ & $\begin{array}{l}0.018 \\
(0.042)\end{array}$ \\
\hline stable_work & $\begin{array}{l}-0.140 * * * \\
(0.022)\end{array}$ & $\begin{array}{l}-0.012 \\
(0.034)\end{array}$ & $\begin{array}{l}-0.085^{* * *} \\
(0.027)\end{array}$ & $\begin{array}{l}-0.021 \\
(0.030)\end{array}$ & $\begin{array}{l}-0.067 * * * \\
(0.024)\end{array}$ & $\begin{array}{l}-0.024 \\
(0.037)\end{array}$ \\
\hline income & $\begin{array}{l}-0.119 * * * \\
(0.028)\end{array}$ & $\begin{array}{l}-0.057 * * \\
(0.027)\end{array}$ & $\begin{array}{l}-0.118 * * * \\
(0.035)\end{array}$ & $\begin{array}{l}-0.089 * * \\
(0.037)\end{array}$ & $\begin{array}{l}-0.100^{* * * *} \\
(0.025)\end{array}$ & $\begin{array}{l}-0.097^{* *} \\
(0.045)\end{array}$ \\
\hline money_home & $\begin{array}{l}-0.028^{*} \\
(0.016)\end{array}$ & $\begin{array}{l}-0.018 \\
(0.011)\end{array}$ & $\begin{array}{l}-0.062^{* * *} \\
(0.022)\end{array}$ & $\begin{array}{l}-0.043 * * * \\
(0.012)\end{array}$ & $\begin{array}{l}-0.043^{* *} \\
(0.019)\end{array}$ & $\begin{array}{l}-0.041^{* *} \\
(0.016)\end{array}$ \\
\hline principal & $\begin{array}{l}0.031 * * * \\
(0.008)\end{array}$ & $\begin{array}{l}0.009 \\
(0.007)\end{array}$ & $\begin{array}{l}-0.003 \\
(0.004)\end{array}$ & $\begin{array}{l}-0.000 \\
(0.003)\end{array}$ & $\begin{array}{l}-0.008^{* *} \\
(0.004)\end{array}$ & $\begin{array}{l}-0.004 \\
(0.003)\end{array}$ \\
\hline loan_start & $\begin{array}{l}-0.004 \\
(0.003)\end{array}$ & $\begin{array}{l}-0.006^{* * *} \\
(0.001)\end{array}$ & $\begin{array}{l}-0.009 * * * \\
(0.001)\end{array}$ & $\begin{array}{l}-0.010 * * * \\
(0.002)\end{array}$ & $\begin{array}{l}-0.011^{* * *} \\
(0.001)\end{array}$ & $\begin{array}{l}-0.013 * * * \\
(0.003)\end{array}$ \\
\hline install_number & $\begin{array}{l}-0.001 \\
(0.001)\end{array}$ & $\begin{array}{l}0.001 \\
(0.001)\end{array}$ & $\begin{array}{l}0.002 * * \\
(0.001)\end{array}$ & $\begin{array}{l}0.002 * * \\
(0.001)\end{array}$ & $\begin{array}{l}0.002 * * * \\
(0.001)\end{array}$ & $\begin{array}{l}0.003 * * \\
(0.001)\end{array}$ \\
\hline interest_rate & $\begin{array}{l}0.031 * * * \\
(0.005)\end{array}$ & $\begin{array}{l}0.001 \\
(0.005)\end{array}$ & $\begin{array}{l}-0.000 \\
(0.004)\end{array}$ & $\begin{array}{l}-0.007 * * * \\
(0.002)\end{array}$ & $\begin{array}{l}-0.007 \\
(0.004)\end{array}$ & $\begin{array}{l}-0.011^{* * *} \\
(0.003)\end{array}$ \\
\hline net & $\begin{array}{l}-0.292 * * * \\
(0.030)\end{array}$ & $\begin{array}{l}-0.076^{*} \\
(0.040)\end{array}$ & $\begin{array}{l}-0.105^{* * * *} \\
(0.019)\end{array}$ & $\begin{array}{l}-0.059 * * \\
(0.025)\end{array}$ & $\begin{array}{l}-0.050^{* *} \\
(0.021)\end{array}$ & $\begin{array}{l}-0.039 * * \\
(0.018)\end{array}$ \\
\hline
\end{tabular}


Table 6 continued

First-stage Second-stage First-stage Second-stage First-stage Second-stage

(a)

(b)

(c)

(d)

(e)

(f)

\begin{tabular}{lllllll}
\hline$R^{2}$ & 0.29 & 0.12 & 0.15 & 0.11 & 0.17 & 0.11 \\
Kleibergen-Paap F stat & 37.81 & & 9.20 & & 7.52 &
\end{tabular}

$* p<0.1$; ** $p<0.05$; *** $p<0.01$. Standard errors clustered at the national level in parentheses. co_yes $=1$ if the borrower has a cosigner; co_weak $=1$ if the cosigner is next of kin, spouse, sibling, other relative; co_close $=1$ if the cosigner is next of kin, spouse, sibling. Not significant covariates: edu_primary, edu_secondary, edu_bachelor, children, Italian_lang, Italy_since, savings, cons_lending. Obs. $=1789$

the sign is reverted in column (e), thus indicating that close relatives tend to avoid cosigning larger loans. On the other hand, lengthier loans (install_number) are more likely to be supported by kinship-related cosigners (columns (c) and (e)), although exhibiting higher default rates (columns (d) and (f)). ${ }^{22}$

Furthermore, the negative sign of the parameter of loan_start in columns (c) and (e) indicates that more recent credit agreements are less frequently associated to the presence of a cosigner being a relative, which could be the result of a change in the lender's guarantee policy. Moreover, a negative sign of loan_start in the second stage regressions (columns (b), (d) and (f)) suggests that defaults are less likely to occur on more recent loans. This can have at least two possible explanations. The first is that client's screening process has been more accurate on newer loans thanks to the lender's increased experience (since its establishment) in managing credit. The second possible interpretation is that this evidence reflects the fact that more recent loans are those reporting a fewer number of repaid installment. This is consistent with the lender's policy of recording defaults only after a sufficient number of installments being overdue. ${ }^{23}$

As for the other terms of contract, we observe that higher interest rates (interest_rate) are positively correlated with the presence of a cosigner (column (a)), evidence that may be related to the riskiness of the projects involved. One possible reason for the fact that higher interest rates correspond to a lower probability of default (columns (d) and (f)) can be that more favorable conditions may have been renegotiated with customers having repayment difficulties but then defaulted afterwards.

Rather interesting is the negative sign associated to the presence of informal network guarantees (net), both in the first and in the second-stage regressions. In first-stage regressions (columns (a), (c) and (e)) this confirms that there is a relevant degree of substitutability between cosigning and informal guarantees. In second-stage regressions (columns (b), (d) and (f)), the negative sign suggests that also the presence of

\footnotetext{
22 Being highly correlated with principal and install_number, the installment amount has been dropped from the estimated equations. Alternative specifications replacing loan principal with the installment amount provide similar indications.
}

23 See supra note 15. 
informal networks tends to be associated to higher repayment rates, even though this effect is much lower in magnitude compared to the presence of a cosigner.

We also find that a higher income is negatively correlated with a reduced cosigner presence (columns (a), (c) and (e)), and tends to decrease the default rate (columns (b), (d) and (f)). In fact, it is expected that richer borrowers both have lower chances to default and are more often waived from submitting guarantees. ${ }^{24}$ Similar interpretations hold for borrowers with stable working positions (stable _work), exhibiting a reduced cosigner presence (columns (a), (c) and (e)), and to house ownership (house_own), being associated to lower default rates (column (b)). There is also evidence that professional education ( $\left.e d u \_p r o f\right)$ corresponds to better repayment rates (columns (d) and (f)), perhaps because of the higher chances of employment. This may also explain a lower likelihood of being required guarantees (columns (c) and (e)). Higher education, instead, is likely to simply reflect borrowers' wealthier background, which may eventually increase the probability of having a cosigner (columns (a), (c) and (e)), but without being associated to better repayment performance.

As for the parameter related to money_home we find that it is negative, both in first and second stage regressions. On the one hand, the first result (columns (a), (c) and (e)) possibly reflects the fact that borrowers sending money abroad less frequently have the chance to find kinship-related cosigners in the host country. On the other hand, there does not seem to be any specific economic meaning for their better attitude towards repayment (columns (d) and (f)), which could be the mere result of a positive association between variables with no causal implications. For instance, better standards of living may contemporaneously reduce the likelihood of default while also increasing the possibility for migrants to send money to their families.

Parameters related to personal treats of the borrower are also sometimes informative. First, younger individuals (birth_year) more frequently have loans cosigned by relatives (column (c)), and this could be justified by their comparative lack of experience in managing money, which may eventually result in higher default rates (column (d)). Males (gender) generally show worse repayment behavior (columns (b), (d) and (f)), a fact that has been already observed in several contexts (Khandker et al. 1995; Hulme 1991, among others), and which is often connected to non-productive uses of money. The variable married is positively associated with the likelihood of having a cosigner, which could be explained by the fact that spouses are often used as guarantors (columns (a), (c) and (e)). Other parameters related to personal traits of the borrower are rarely significant.

The outcome of the regressions performed on the full sample of borrowers is illustrated in Table 7. In general, estimates are robust to changes in the sample of loans analyzed. In particular, slightly less efficient parameters are associated to the presence of various types of cosigners compared to parameters' estimates obtained using the sub-sample of borrowers having at least 6-month outstanding loans. Such evidence suggests that removing the ambiguities related to more recent loans helps offering a clearer picture of the factors at play.

\footnotetext{
24 On the contrary, savings are not particularly indicative. Like other non-significant parameters they have not been reported in Table 6 .
} 
Table 7 Effect of the presence of cosigners on loan default rates_-Job sector Fixed Effects—Full sample

\begin{tabular}{|c|c|c|c|c|c|c|}
\hline & $\begin{array}{l}\text { First-stage } \\
\text { (a) }\end{array}$ & $\begin{array}{l}\text { Second-stage } \\
\text { (b) }\end{array}$ & $\begin{array}{l}\text { First-stage } \\
\text { (c) }\end{array}$ & $\begin{array}{l}\text { Second-stage } \\
\text { (d) }\end{array}$ & $\begin{array}{l}\text { First-stage } \\
\text { (e) }\end{array}$ & $\begin{array}{l}\text { Second-stage } \\
\text { (f) }\end{array}$ \\
\hline \multirow[t]{2}{*}{ threshold } & $0.145^{* * * *}$ & & $0.084 * * *$ & & $0.051 * * *$ & \\
\hline & $0.053^{*}$ & & $0.020 * * *$ & & 0.017 & \\
\hline co_yes & & $\begin{array}{l}-0.213 \\
(0.137)\end{array}$ & & & & \\
\hline co_weak & & & & $\begin{array}{l}-0.370^{* *} \\
(0.177)\end{array}$ & & \\
\hline co_close & & & & & & $\begin{array}{l}-0.607 * * \\
(0.300)\end{array}$ \\
\hline birth_year & $\begin{array}{l}0.003^{*} \\
(0.002)\end{array}$ & $\begin{array}{l}0.001 \\
(0.001)\end{array}$ & $\begin{array}{l}0.003 * * * \\
(0.001)\end{array}$ & $\begin{array}{l}0.001 \\
(0.001)\end{array}$ & $\begin{array}{l}0.001 \\
(0.001)\end{array}$ & $\begin{array}{l}0.001 \\
(0.001)\end{array}$ \\
\hline gender & $\begin{array}{l}0.049 * * \\
(0.023)\end{array}$ & $\begin{array}{l}0.035 * * * \\
(0.011)\end{array}$ & $\begin{array}{l}0.037 * \\
(0.020)\end{array}$ & $\begin{array}{l}0.039 * * * \\
(0.013)\end{array}$ & $\begin{array}{l}0.010 \\
(0.015)\end{array}$ & $\begin{array}{l}0.031 * * \\
(0.014)\end{array}$ \\
\hline edu_high & $\begin{array}{l}0.071 * * * \\
(0.023)\end{array}$ & $\begin{array}{l}0.004 \\
(0.013)\end{array}$ & $\begin{array}{l}0.064 * * * \\
(0.018)\end{array}$ & $\begin{array}{l}0.013 \\
(0.016)\end{array}$ & $\begin{array}{l}0.049 * * * \\
(0.016)\end{array}$ & $\begin{array}{l}0.019 \\
(0.023)\end{array}$ \\
\hline$e d u \_p r o f$ & $\begin{array}{l}0.035 \\
(0.037)\end{array}$ & $\begin{array}{l}-0.018 \\
(0.015)\end{array}$ & $\begin{array}{l}-0.030 \\
(0.023)\end{array}$ & $\begin{array}{l}-0.037 * * \\
(0.015)\end{array}$ & $\begin{array}{l}-0.051^{* *} \\
(0.022)\end{array}$ & $\begin{array}{l}-0.056^{* *} \\
(0.022)\end{array}$ \\
\hline married & $\begin{array}{l}0.102 * * * \\
(0.021)\end{array}$ & $\begin{array}{l}0.015 \\
(0.012)\end{array}$ & $\begin{array}{l}0.091 * * * \\
(0.020)\end{array}$ & $\begin{array}{l}0.027 \\
(0.016)\end{array}$ & $\begin{array}{l}0.054 * * * \\
(0.019)\end{array}$ & $\begin{array}{l}0.026 \\
(0.021)\end{array}$ \\
\hline house_own & $\begin{array}{l}-0.005 \\
(0.048)\end{array}$ & $\begin{array}{l}-0.026^{*} \\
(0.014)\end{array}$ & $\begin{array}{l}0.037 \\
(0.057)\end{array}$ & $\begin{array}{l}-0.011 \\
(0.028)\end{array}$ & $\begin{array}{l}0.058 \\
(0.040)\end{array}$ & $\begin{array}{l}0.011 \\
(0.035)\end{array}$ \\
\hline stable_work & $\begin{array}{l}-0.120 * * * \\
(0.020)\end{array}$ & $\begin{array}{l}-0.010 \\
(0.031)\end{array}$ & $\begin{array}{l}-0.068 * * * \\
(0.023)\end{array}$ & $\begin{array}{l}-0.010 \\
(0.026)\end{array}$ & $\begin{array}{l}-0.051^{* *} \\
(0.021)\end{array}$ & $\begin{array}{l}-0.016 \\
(0.030)\end{array}$ \\
\hline income & $\begin{array}{l}-0.113 * * * \\
(0.028)\end{array}$ & $\begin{array}{l}-0.051^{* *} \\
(0.025)\end{array}$ & $\begin{array}{l}-0.113 * * * \\
(0.032)\end{array}$ & $\begin{array}{l}-0.069 * * \\
(0.029)\end{array}$ & $\begin{array}{l}-0.083^{* * * *} \\
(0.022)\end{array}$ & $\begin{array}{l}-0.077 * * \\
(0.036)\end{array}$ \\
\hline money_home & $\begin{array}{l}-0.025 \\
(0.018)\end{array}$ & $\begin{array}{l}-0.015 \\
(0.010)\end{array}$ & $\begin{array}{l}-0.053^{* *} \\
(0.022)\end{array}$ & $\begin{array}{l}-0.029 * * * \\
(0.009)\end{array}$ & $\begin{array}{l}-0.030^{* *} \\
(0.015)\end{array}$ & $\begin{array}{l}-0.028^{* *} \\
(0.012)\end{array}$ \\
\hline principal & $\begin{array}{l}0.034 * * * \\
(0.009)\end{array}$ & $\begin{array}{l}0.008 \\
(0.007)\end{array}$ & $\begin{array}{l}-0.003 \\
(0.003)\end{array}$ & $\begin{array}{l}-0.001 \\
(0.002)\end{array}$ & $\begin{array}{l}-0.007 * * * \\
(0.002)\end{array}$ & $\begin{array}{l}-0.004 \\
(0.003)\end{array}$ \\
\hline loan_start & $\begin{array}{l}-0.006^{* * *} \\
(0.002)\end{array}$ & $\begin{array}{l}-0.005^{* * * *} \\
(0.001)\end{array}$ & $\begin{array}{l}-0.009 * * * \\
(0.001)\end{array}$ & $\begin{array}{l}-0.007 * * * \\
(0.002)\end{array}$ & $\begin{array}{l}-0.011^{* * *} \\
(0.001)\end{array}$ & $\begin{array}{l}-0.011^{* * *} \\
(0.003)\end{array}$ \\
\hline install_number & $\begin{array}{l}-0.000 \\
(0.001)\end{array}$ & $\begin{array}{l}0.001 \\
(0.001)\end{array}$ & $\begin{array}{l}0.001 * * \\
(0.001)\end{array}$ & $\begin{array}{l}0.002 * \\
(0.001)\end{array}$ & $\begin{array}{l}0.002 * * * \\
(0.001)\end{array}$ & $\begin{array}{l}0.002 * \\
(0.001)\end{array}$ \\
\hline interest_rate & $\begin{array}{l}0.027 * * * \\
(0.004)\end{array}$ & $\begin{array}{l}0.002 \\
(0.004)\end{array}$ & $\begin{array}{l}0.002 \\
(0.002)\end{array}$ & $\begin{array}{l}-0.003^{*} \\
(0.002)\end{array}$ & $\begin{array}{l}-0.004 \\
(0.003)\end{array}$ & $\begin{array}{l}-0.006^{* * *} \\
(0.002)\end{array}$ \\
\hline net & $\begin{array}{l}-0.257 * * * \\
(0.034)\end{array}$ & $\begin{array}{l}-0.056 \\
(0.038)\end{array}$ & $\begin{array}{l}-0.093^{* * *} \\
(0.017)\end{array}$ & $\begin{array}{l}-0.036^{* *} \\
(0.018)\end{array}$ & $\begin{array}{l}-0.037 * * \\
(0.018)\end{array}$ & $\begin{array}{l}-0.024^{*} \\
(0.014)\end{array}$ \\
\hline
\end{tabular}


Table 7 continued

First-stage Second-stage First-stage Second-stage First-stage Second-stage

(a)

(b)

(c)

(d)

(e)

(f)

\begin{tabular}{lllllll}
\hline$R^{2}$ & 0.29 & 0.14 & 0.15 & 0.13 & 0.17 & 0.13 \\
Kleibergen-Paap F stat & 32.47 & & 13.20 & & 7.76 &
\end{tabular}

$* p<0.1$; ** $p<0.05$; *** $p<0.01$. Standard errors clustered at the national level in parentheses. co_yes $=1$ if the borrower has a cosigner; co_weak $=1$ if the cosigner is next of kin, spouse, sibling, other relative; co_close $=1$ if the cosigner is next of kin, spouse, sibling. Not significant covariates: edu_primary, edu_secondary, edu_bachelor, children, Italian_lang, Italy_since, savings, cons_lending. Obs. $=2350$

Next, we seek to determine whether key parameters are affected by the introduction of a proxy of expected cosigner's intervention in the loan repayment process. Estimates are reported in Table 8, both for 6-month outstanding loans (Panel (1)) and for the full sample (Panel (2)). ${ }^{25}$

The first thing to notice is the positive and significant parameter associated to our measure of expected cosigner's intervention in first-stage regressions (columns (a), (c) and (e)), suggesting that differences between borrowers and cosigners in their capability to fulfill financial obligations increase the likelihood of the former to actually offer a personal guarantee to the latter.

Our measure of cosigners' intervention reports an expected negative sign and is significant only in the regressions pertaining to relations of close kinship (column (f)). This suggests that siblings, spouses, or next-of-kin exhibiting a higher financial capability compared to the borrower can effectively reduce default rates. Since the proxy of cosigners' intervention is built on financial capability, we interpret this evidence as a direct financial contribution to loan repayment, rather than simple psychological pressure, the latter being captured by the dummies co_yes,co_weak, and co_close, reflecting the effect of the mere presence of various categories of cosigners to default reduction. In relation to this, a relevant outcome is that the parameters of co_weak and co_close still remain significant, possibly indicating that relatives are likely to financially contribute to loan repayment while also effectively spurring the borrower to diligently perform.

Finally, it is interesting to observe that the parameters associated to co_weak and co_close in Table 8 are lower in magnitude compared to the corresponding values in Tables 6 and 7. Since we assume that these estimated coefficients reflect the borrower's contribution to the reduction of default conditional (Table 8) and non-conditional (Tables 6 and 7) to the cosigner's expected financial support, their lower magnitude turns out to be consistent with the actual participation of cosigners in the repayment process. By computing the ratio between the parameters in Table 8 and the corresponding parameters in Tables 6 and 7, one may infer the extent of the borrower's concurrence in loan repayment, whereas the remaining share can be interpreted as the cosigner's contribution. For example, referring to the 6-month outstanding loan model in Table 8 (Panel (1)) we calculated that borrowers contribute to $96.9 \%$ of loan repay-

\footnotetext{
25 We only report relevant parameters, since all the remaining covariates provide the same indications given in the previous analysis. Full output is available upon request.
} 
Table 8 Effect of cosigners' presence and expected financial support on loan default rates-Job sector Fixed Effects

\begin{tabular}{|c|c|c|c|c|c|c|}
\hline \multirow{2}{*}{$\begin{array}{l}\text { Panel (1) 6-m. } \\
\text { Outstanding loans }{ }^{\mathrm{a}}\end{array}$} & First-stage & Second-stage & First-stage & Second-stage & First-stage & Second-stage \\
\hline & (a) & (b) & (c) & (d) & (e) & (f) \\
\hline \multirow[t]{2}{*}{ threshold } & $0.101 * * *$ & & $0.061 * *$ & & $0.055^{* * * *}$ & \\
\hline & $(0.037)$ & & $(0.023)$ & & $(0.020)$ & \\
\hline \multirow{2}{*}{$\begin{array}{l}\text { E.cosigner's } \\
\text { intervention }\end{array}$} & $0.684 * * *$ & 0.167 & $0.210 * * *$ & -0.048 & $0.078 * *$ & $-0.084^{* *}$ \\
\hline & $(0.038)$ & $(0.164)$ & $(0.036)$ & $(0.072)$ & $(0.033)$ & $(0.040)$ \\
\hline \multirow[t]{2}{*}{ co_yes } & & -0.353 & & & & \\
\hline & & $(0.231)$ & & & & \\
\hline \multirow[t]{2}{*}{ co_weak } & & & & $-0.503 * *$ & & \\
\hline & & & & $(0.219)$ & & \\
\hline \multirow[t]{2}{*}{ co_close } & & & & & & $-0.607 * *$ \\
\hline & & & & & & $(0.293)$ \\
\hline$R^{2}$ & 0.43 & 0.14 & 0.17 & 0.13 & 0.17 & 0.12 \\
\hline $\begin{array}{l}\text { Kleibergen-Paap } F \\
\text { stat }\end{array}$ & 19.13 & & 8.36 & & 9.86 & \\
\hline
\end{tabular}

\begin{tabular}{|c|c|c|c|c|c|c|}
\hline Panel (2) Full sample ${ }^{b}$ & (a) & (b) & (c) & (d) & (e) & (f) \\
\hline threshold & $\begin{array}{l}0.078 * \\
(0.043)\end{array}$ & & $\begin{array}{l}0.063 * * * \\
(0.021)\end{array}$ & & $\begin{array}{l}0.042 * * \\
(0.017)\end{array}$ & \\
\hline $\begin{array}{l}\text { E.cosigner's } \\
\text { intervention }\end{array}$ & $\begin{array}{l}0.647 * * * \\
(0.049)\end{array}$ & (0.190) & $(0.038)$ & $\begin{array}{l}-0.038 \\
(0.055)\end{array}$ & $\begin{array}{l}0.087 * * * \\
(0.029)\end{array}$ & $\begin{array}{l}-0.057 * * \\
(0.028)\end{array}$ \\
\hline co_yes & & $\begin{array}{l}-0.308 \\
(0.287)\end{array}$ & & & & \\
\hline co_weak & & & & $\begin{array}{l}-0.350 * \\
(0.198)\end{array}$ & & \\
\hline co_close & & & & & & $\begin{array}{l}-0.543^{*} \\
(0.319)\end{array}$ \\
\hline$R^{2}$ & 0.38 & 0.15 & 0.17 & 0.13 & 0.18 & 0.12 \\
\hline $\begin{array}{l}\text { Kleibergen-Paap } F \\
\text { stat }\end{array}$ & 16.49 & & 10.62 & & 10.18 & 10.70 \\
\hline
\end{tabular}

The set of covariate is the same as in previous estimates

$* p<0.1$; $* * p<0.05$; $* * * p<0.01$. Standard errors in parentheses. ${ }^{\mathrm{a}}$ Obs. $=1789$. ${ }^{\mathrm{b}}$ Obs. $=2350$

co_yes $=1$ if the borrower has a cosigner; co_weak $=1$ if the cosigner is next of kin, spouse, sibling, other relative; co_close $=1$ if the cosigner is next of kin, spouse, sibling

ment when cosigners are related to them by weak kinship, against 88 per cent when strong kinship is involved. ${ }^{26}$ When looking at the full set of outstanding loans (Panel

\footnotetext{
26 Percentages have been computed as the ratio of parameters in columns (d) and (f) in Table 8 (Panel (1)) with the corresponding parameters in Table 6. In details, the figures are 0.503/0.519 and 0.607/0.690.
} 
(2)), this percentage looks less far apart, since it turns out that borrowers contribute to $94.6 \%$ of loan repayment in case of weak kinship relations with the cosigner, against $89.5 \%$ in the case of strong kinship. ${ }^{27}$ Hence, the stronger the relationship with the borrower, the more generous is the cosigner's financial support.

\section{Conclusions}

In this paper we have conducted an analysis on the effect that kinship relations between MFIs and cosigners have on loan repayment.

From univariate descriptive statistics comparing borrowers with and without cosigners, we have observed that the two categories perform almost the same in terms of repayment rates. However, it is quite likely that such evidence is due to some form of endogeneity, such as the possibility of the lender asking riskier customers to have a cosigner. Another possible explanation is that better borrowers have higher reputational concerns, which may lead them to exclusively rely on their own financial resources for loan reimbursement. Conversely, bad borrowers may be tempted to exploit cosigners' financial support in repayment, so as to reduce the risk of their own assets being seized in case of default.

We have used instrumental variable techniques (Two-Stage Least Squares) to address such possible biases. Our instrument consists of an exogenous rule set up by the lender according to which loans above $€ 5000$ should have a cosigner. This rule, conditional on the inclusion of a continuous measure of the amount lent, allowed for identification of the role played by various levels of kinship proximity in explaining the borrowers' default rate. We have measured the effect of: (a) having a cosigner versus having none; (b) having a cosigner who is a relative versus either having none or having a cosigner who is not a relative; (c) having a cosigner who is a close relative (next-of-kin, sibling, spouse) versus either having no cosigner or one who is not a close relative.

Estimates have shown that cosigned loans tend to default less frequently, although the effect is rather weak. More noticeably, we have obtained strong and significant evidence backing the fact that borrowers related to cosigners by stronger kinship ties are more likely to exhibit better repayment performance. In particular, the closer the borrower-cosigner kinship relation, the lower the probability of default is.

In terms of the borrower-cosigner relationship, the considerations stemming from our estimates are twofold. On the one hand, as aforementioned, relatives and individuals who are very close to the borrower appear more likely to exert effective pressure on her compared to other individuals, since they are in a better position to screen and monitor her actions. On the other hand, relatives are often motivated by solidarity concerns, and this can lead to their direct intervention in the repayment process. We have tried to disentangle such features by introducing a measure of expected cosigner's financial support in the estimated equation. We have found that actual contribution to loan repayment occurs when the cosigner is a close relative, although this effect

\footnotetext{
27 Percentages have been computed as the ratio of parameters in columns (d) and (f) in Table 8 (Panel (2)) with the corresponding parameters in Table 7 . In details, the figures are 0.350/0.370 and 0.543/0.607.
} 
does not overcome the positive and significant effect on reducing default rates that the presence of a closely related cosigner brings.

In conclusion, a comprehensive evaluation of our empirical findings seems to provide support for both the principle of "excess solidarity" and the idea that borrowers are better monitored by individuals that are linked to them by closer social ties. As a policy indication, this paper suggests that cosigner-based microfinance programs should pay considerable attention to the impact that different levels of social ties linking guarantors and borrowers have on repayment behavior. Cosigners related to borrowers by closer kinship should generally be privileged.

\section{References}

Banerjee AV, Besley T, Guinnane T (1994) Thy neighbor's keeper: the design of a credit cooperative with theory and a test. Q J Econ 109(2):491-515

Botti F, Corsi M (2010) A social performance analysis of Italian Microfinance, Centre Emile Bernheim Working Paper n. 10/020

Botti F, Negro MC (2014) Country profiles: Italy. In: Bendig M, Unterberg M, Sarpong B (eds) Overview of the Microcredit Sector in the European Union-European Microfinance Network (EMN) 2012-13 Overview Survey

Besanko D, Thakor AV (1987) Collateral and rationing: sorting equilibria in monopolistic and competitive credit markets. Int Econ Rev 28(3):671-689

Besley T, Coate S (1995) Group lending, repayment incentives and social collateral'. J Dev Econ 46:1-18

Bond P, Ray AS (2008) Cosigned vs. group loans. J Dev Econ 85(1-2):58-80

Bryan GT, Karlan D, Zinman J (2012) You can pick your friends, but you need to watch them: loan screening and enforcement in a referrals field experiment, NBER Working Paper No. 17883

Churchill C (1999) Client-focused lending: the art of individual lending. Calmeadow, Toronto

Dalla Pellegrina L (2011) Microfinance and investment: a comparison with bank and informal lending. World Dev 39(6):882-897

Gangopadhyay S, Lensink R (2005) Cosigned Loans versus Joint Liability Lending in an Adverse Selection Model, Research Paper No: 09-05. Centre for Analytical finance, Indian School of Business

Guttman JM (2007) Repayment Performance in Microcredit Programs: Theory and Evidence, Networks Financial Institute at Indiana State University (NFI) Working Paper No. 11-2007

Hulme D (1991) Field reports. The Malawi Mudzi fund: daughter of Grameen, Journal of International Development 3(3):427-32

Jaunaux L (2007) Crédit individuel et informalité sont-ils compatibles? Une expérience brésilienne. Economie Internationale 112:99-131

Jaunaux L, Venet B (2009) Individual Microcredit and Social Pressure, paper presented at the First European Research Conference on Microfinance, Bruxelles, LEDa Publications_Dauphine University, Paris

Jayo B, González A, Conzett C (2010) Overview of the microcredit sector in the European union (), European Microfinance Network Working Paper no. 6

Johnstone DB, Marcucci P (2006) Financially Sustainable Student Loan Programs: The Management of Risk in the Quest for Private Capital, Prepared as an Issue Brief for the Global Center on Private Financing of Higher Education at the Institute for Higher Education Policy, Washington, DC. 2007

Karlan D, Mobius M, Rosenblat T, Szeidl A (2009) Measuring Trust in Peruvian Shantytowns (unpublished)

Khandker S, Khalily B, Kahn Z (1995) Grameen banks: performance and sustainability, World Bank Discussion Paper 306, Washington, DC

Klonner S, Rai A (2008) Cosigners as Collateral, Department of Economics Working Papers 2008-04, Williams College, MA

La Ferrara E (2003) Kinship groups and reciprocity: a model of credit transactions in Ghana. Am Econ Rev 93(5):1730-1751

Ledgerwood J (1999) Microfinance handbook: an institutional and financial perspective. The World Bank, Washington DC

Negro MC (2013) Italia. In: Pizzo G, Tagliavini G (eds) Dizionario di microfinanza. Carocci Editore, Roma 
Pitt MM, Khandker S (1998) The Impact of Group-Based Credit Programs on Poor Households in Bangladesh: Does the Gender of Participants Matter? J Polit Econ 106(5):958-996

Sharma M, Zeller M (1997) Repayment performance in group-based credit programs in Bangladesh: an empirical analysis. World Dev 25(10):1731-1742

Stiglitz JE (1990) Peer monitoring and credit markets. World Bank Econ Rev 4(3):351-366 